\title{
Small Scale Integrated Sustainable Roof Design (Case Study in Surakarta City)
}

\author{
Purwanti Sri Pudyastuti", Findria Kalista, Gurawan Djati Wibowo, Hermono S Budinetro \\ Department of Civil Engineering, Faculty of Engineering, Muhammadiyah University of Surakarta, Surakarta, Indonesia
}

Received February 25, 2020; Revised June 24, 2020; Accepted July 7, 2020

Copyright $\odot 2020$ by authors, all rights reserved. Authors agree that this article remains permanently open access under the terms of the Creative Commons Attribution License 4.0 International License.

\begin{abstract}
The city of Surakarta is one of the densest cities in Indonesia. From the Surakarta Central Bureau of Statistics, the population density of Surakarta City reaches 12,000 people per one square kilometre. This certainly affects the magnitude of the increasing demand for clean water resources and the reduction of rainwater catchment areas which can lead to disasters such as floods and landslides. Therefore, a simple, sustainable roof design innovation which is easy to be built, is required, particularly in the residential area. This simple, sustainable roof is designed for a house with type 70/120 and inhabited by four people. The sustainable roof components are an extensive green roof with 5.1 meters long, 2.3 meters wide and 0.8-meter height using sedum grass, an application of rainwater harvesting with a capacity of 22000 litres to supply water demand for the inhabitants, as well as electricity for a pump that uses powered solar panel 100 WP.
\end{abstract}

Keywords Flood, Green Roof, Rainwater Harvesting, Sustainable Roof Design

\section{Introduction}

Surakarta is one of the most densely populated cities in Indonesia. According to data taken from the Surakarta Central Bureau of Statistics, the Population Density of Solo City reaches 12,000 inhabitants per one square kilometre. That is certainly a big influence on natural resource needs that are increasing every day. Besides that, global warming is one of the biggest impacts of the destruction of this earth. So that awareness of environmental hazards and scarcity is needed. Only wise plans will allow humans to enjoy progress. Therefore we need a simple design that can change the environment. With a sustainable roof theme, an important component of an eco-friendly house is obtained. The green roof is the roof of a building partially or completely covered with vegetation and growing media, planted on a waterproof membrane. It also includes additional layers such as root barriers and drainage as an irrigation system. In general, the benefits of green roofs are to reduce the level of air pollution, reduce air temperature, conserve water, and reduce noise/noise pollution, display the beauty of aspects of the building (aesthetics), and increase the biodiversity of the city. Wilkinson et al. (2015) reported that green roofs could reduce carbon emission and contribute to carbon zero target. A study conducted by Ahmed (2016) found that green roofs can be used to reduce side effects caused by urbanization and industrialization of urban areas to a reasonable percentage. In addition, according to a study conducted by Pudyastuti and Saputra (2018), the runoff could be reduced by $18 \%$ when the green rooftop applied in the selected flat-roofed buildings in Surakarta City.

Rainwater harvesting has been widely applied to fulfil the water demand in the drought-prone areas such as Gunung Kidul Regency in Yogyakarta Province. Rainwater harvesting gives benefits such as decreasing flood risk and creating water source development to fulfil clean water demand. Rainwater storage could be located on the land surface or underground. When it is located underground, a pump required to elevate and distribute the rainwater. Photovoltaic or solar panels could be applied as an energy source to operate the pump. The combination of the green rooftop, rainwater harvesting, and solar panels will be applied in this study to design a small scale integrated sustainable roof system for a household. The term "small scale" in this paper refers to the typically small size housing in Indonesia. The house in this study has 2 (two) types of roof, i.e. pitched roof with tiles and flat roof as a green roof.

\section{Research Method}

This study aims to make a model of sustainable integrated roof design in a house. The data used in this 
study was secondary, i.e. the location of the design house, the area of the designed house, rainfall data, and PV specification. The location of the design house can be seen in Figure 1 (b). The rainfall data used in this research are the rainfall data at Pabelan rain gauging station in the years $2004-2018$. This study only used one rain gauging station represented the area of the house location. After conducting rainfall data analysis, the next step was determining the storage required for rainwater harvesting and the energy required for the pump to determine the solar panel capacity. The steps of the study can be seen in Figure 1 (a).

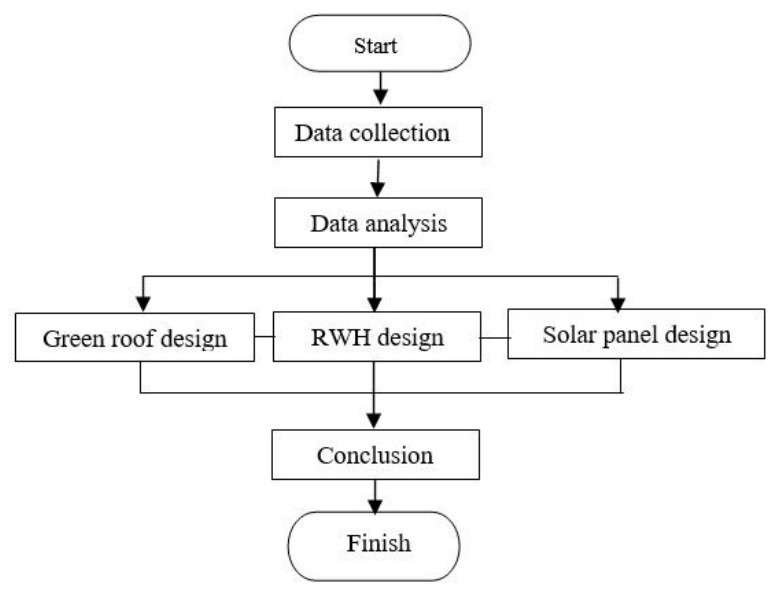

(a)

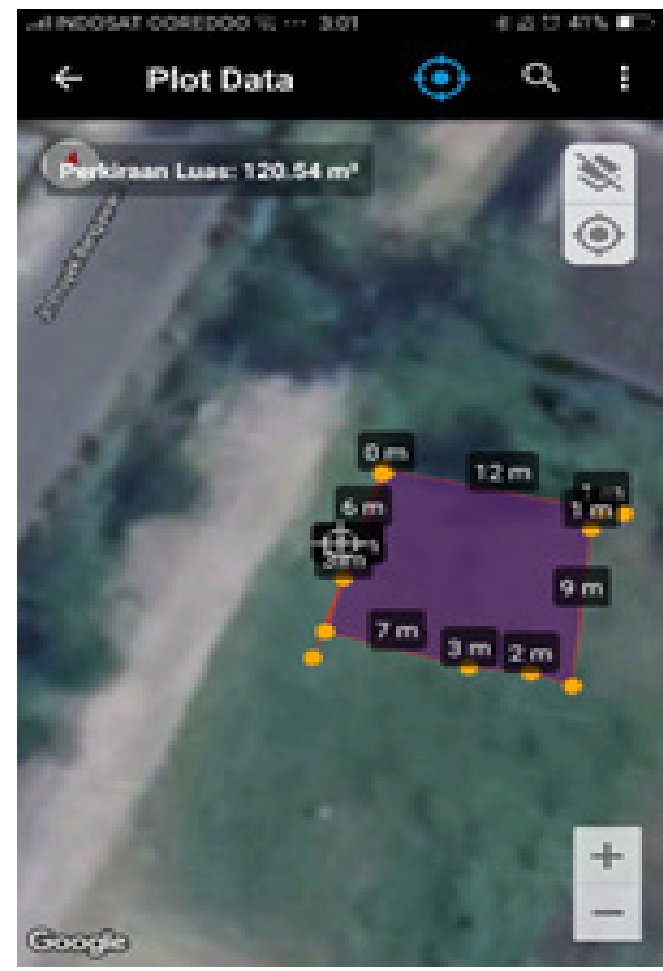

(b)

Figure 1. (a) The steps of the study (RWH = rainwater harvesting), and (b) the location of the designed house

\section{Rainfall Data Analysis}

Before using the available rainfall data obtained from the related institution, the consistency test must be conducted to ensure that rainfall data at the rain gauging station is consistent. The consistency test of rainfall data in this study was conducted by applying the Rescaled Adjusted Partial Sums (RAPS) method (Harto, 1993). The formulas of the RAPS method are as follows:

$$
\mathrm{S}_{\mathrm{k}}^{*}=\frac{S k}{D_{y}^{2}}
$$

with:

$$
\mathrm{K}=0,1,2, \ldots \ldots \ldots . \mathrm{n} \text { ( } \mathrm{n} \text { is number of data) }
$$

$\mathrm{S}_{\mathrm{k}}=\sum_{i+1}^{k}(Y i-\overline{\mathrm{Y}})$ where $\mathrm{Y}_{\mathrm{i}}$ is rainfall data at $\mathrm{i}$, and $\overline{\mathrm{Y}}$ is the average rainfall.

$$
\mathrm{Dy}^{2}=\sum_{i=1}^{n} \frac{(Y i-\bar{Y})^{2}}{n}
$$

\section{Rainwater Harvesting}

Rainwater harvesting has been widely applied to collect, hold, and store rainwater. Rainwater harvesting gives benefits such as provides water sources to fulfil the water demand and reduce flood risk because it can reduce potential runoff. In addition, rainwater harvesting is one method to solve the water scarcity problem in densely populated areas by using a roof stored rainwater tank (Sri Maharjono et al., 2017). The efficiency of a rainwater tank depends on the volume of the reservoir that must be provided (Jayasooriya et al., 2016). The larger reservoir volume will increase the efficiency of rainwater harvesting. The larger the capacity of the rainwater reservoir, the smaller the volume of rainwater that becomes runoff due to not being accommodated by the tank will be. According to Jothiprakash and Sathe (2009), the parameters required to determine the volume of rainwater to be stored are the prevailing hydrologic (rainfall-runoff) condition and the water demand.

This study aims to design the simple, sustainable integrated roof for a house of 70/120 (the building area is $70 \mathrm{~m}^{2}$ built on $120 \mathrm{~m}^{2}$ land area) which is inhabited by four people. There are some methods to determine the volume of rainwater to be stored, such as balanced mass method, Ripple diagram method, analytical method, and sequent peak algorithm method (Jothiprakash and Sathe, 2009). This study applied the Ripple diagram method, as shown in Figure 2 below. Ripple diagram method considers the difference between demand and supply over time. Cumulative rainfall volume is plotted against time to determine the difference between demand and supply. If more peaks are available, the cumulative demand line may be started from each peak. The capacity of the rainwater storage required is equal to the maximum difference between the supply and demand over the period. The Ripple diagram method can be applied if the amount of rainwater available is greater than the water demand. 


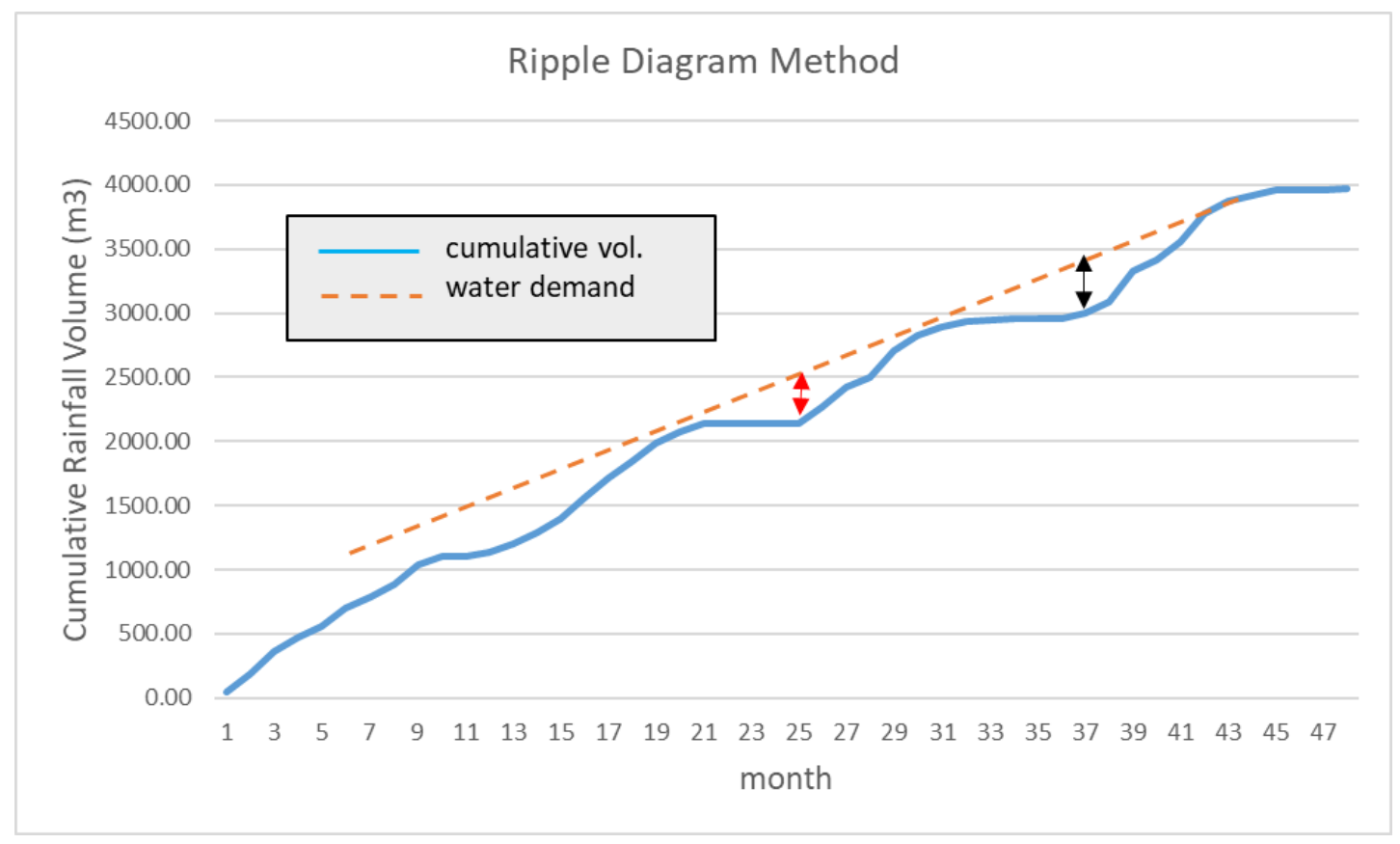

Figure 2. Ripple Diagram Method

The volume of rainfall collected from the roof is calculated using the equation (2) below (Jothiprakash and Sathe, 2009).

$$
\mathrm{V}=\mathrm{C} \text { i A }
$$

where:

$\mathrm{V}=$ volume of rainfall collected from the roof,

$\mathrm{i}=$ rainfall depth,

$\mathrm{A}=$ area of the roof,

$\mathrm{C}=$ roof runoff coefficient which depends on the roof material.

The rainfall data used in this study was rainfall data in years $2004-2018$ obtained from Pabelan rain gauging station.

\section{Solar Panel System}

The solar panel system is utilized in the system planned in this study as an energy source to power the water pump. The use of a water pump in a house is more a tool for distributing water to meet the daily needs of residents. Two ways are often used to calculate the electric power of the pump, namely, full use, and certain needs.

The definition of full use is to rely on the existence and function of the pump as a tool for distributing water for all water usage needs of the occupants of the house. While the notion of use for certain needs is a water pump used only to meet water consumption needs at certain times and purposes only. In this study, it is assumed that the house is inhabited by four people. Solar panels are planned to be utilized because it is efficient and more affordable to take advantage of economic and environmental benefits.

\section{Green Roof}

A green roof is a term used to describe the roof of a green building in the form of a roof filled with plants. In some contexts, the term green roof has the same meaning as a roof garden. Green roofs can absorb rainwater and store it temporarily in the soil so that it can indirectly cool the roof, and the green roof serves as a natural insulation that can cool the surface of the building around 10-25 per cent. Meanwhile, the temperature in the building also dropped by approximately 3-4 degrees compared to the temperature outside the building so that it can reduce the consumption of air conditioning in the room at housing located in hot temperature areas like Surakarta.

The technology of green roof construction has grown rapidly. However, actually, we can still apply simple and relatively inexpensive technology to realize a green roof above our homes. The most important factor to remember is that green roofs require a roof structure that is stronger than conventional roofs. This is due to the extra load that must be supported when you want to make a green roof. The additional load is soil, water, and plants.

\section{Results and Discussion}

\section{Rainfall Characteristic}

The rainfall data used in this study is obtained from one nearest rain gauging station, namely Pabelan rain gauging station. The study only used one rain gauging station because the rainwater harvesting is designed only for one private house. The summary of the statistic of the rainfall data in Pabelan rain gauging station is shown in Table 1 below. 
Table 1. Summary of Statistic of Monthly Rainfall Data (mm) in Pabelan Rain Gauging Station Year 2004 - 2018

\begin{tabular}{ccccccccccccc}
\hline & Jan & Feb & Mar & Apr & May & Jun & Jul & Aug & Sep & Oct & Nov & Dec \\
\hline Mean & 74.1 & 74.5 & 77.2 & 63.7 & 52.2 & 47.8 & 23.9 & 5.4 & 15.3 & 48.2 & 55.0 & 86.0 \\
Standard & & & & & & & & & & & & \\
Deviation & 27.9 & 21.3 & 36.4 & 30.7 & 20.8 & 41.5 & 36.3 & 11.8 & 23.3 & 35.4 & 18.1 & 32.4 \\
Kurtosis & 1.1 & 0.7 & 2.7 & -0.3 & -0.2 & -0.2 & 7.1 & 6.8 & 0.2 & -1.1 & -1.0 & -1.7 \\
Skewness & 1.0 & -0.5 & 0.5 & -0.3 & 0.2 & 0.9 & 2.5 & 2.6 & 1.4 & 0.2 & 0.3 & 0.1 \\
Minimum & 40.0 & 26.0 & 0.0 & 0.0 & 20.0 & 0.0 & 0.0 & 0.0 & 0.0 & 0.0 & 27.0 & 39.0 \\
Maximum & 142.0 & 110.0 & 166.0 & 112.0 & 95.0 & 131.0 & 138.0 & 42.0 & 61.0 & 109.0 & 88.0 & 133.0 \\
\hline
\end{tabular}

It can be seen from the statistic above that there is a significant amount of rainwater that can be collected in the study area. That significant amount of rainwater is a benefit, but on the other hand, it could be a source of flooding if it is not managed appropriately. Rainwater harvesting is one approach to reduce the flood risk as well as to fulfil the domestic water demand.

\section{Green Roof}

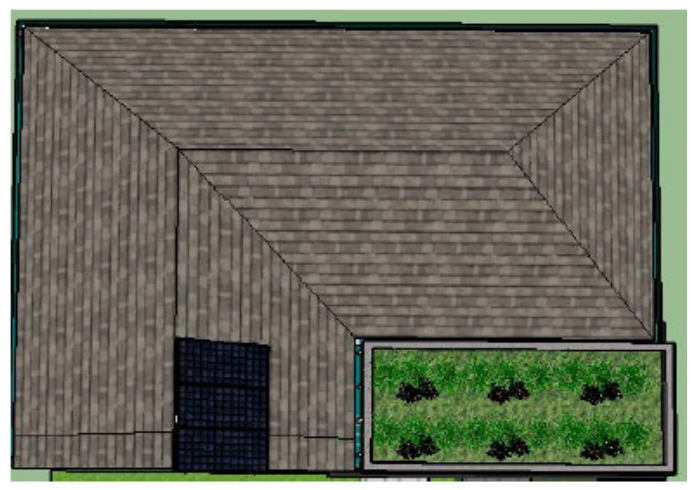

(a)

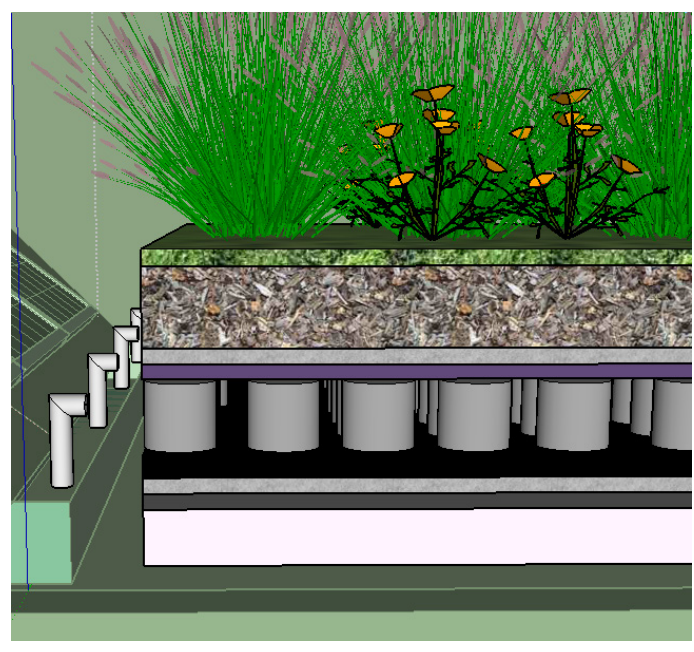

(b)

Figure 3. (a) Location of a green roof, and (b) design of green roof layers

The type of green roof is an extensive green roof with the sedum as the selected plant, because it can grow in the dry season but can absorb water well during the rainy season. In addition, sedum has a wide range of colours, such as red, green, and yellow, which certainly can add aesthetic value to the building. There are seven layers for this design of green roof in Fig 3 (b): the water vapour barrier, The waterproofing and root barrier layer, Layer of drain composite and filtration, Substrate/soil layer, Vegetation/plants. In this study, the green roof was made on a concrete slab. The dimension of the concrete slab is $2.3 \mathrm{~m} \times 5.1 \mathrm{~m}$, with $0.8 \mathrm{~m}$ height of the soil layer with sedum.

\section{Clean Water Demand}

The standard demand for clean water for the domestic purpose was obtained from the SNI 03-7065-2005, that is 120 litres/person/day. An ordinary house was chosen because of the typical size of a conventional house in Indonesia, after that, it was calculated for 4 (four) people inside, and the results are 480 litres/day.

\section{Rainwater Harvesting}

In this study, rainwater fell on the roof tiles of the house, which later flowed into the gutters. From gutters, water will be channelled to rainwater harvesting using pipes. After that, the water will go to the filtration process using fibres, sand, and gravel with a mixture of bricks. Then water can be pumped and reused for household needs. To get the rid of excess water in the rainwater harvesting, there is a drainpipe, which has the function to drain excess water in the rainwater harvesting towards the drainage canal around the house. The rainwater harvesting system is shown in Fig. 5 .

Fig 4 shows the Ripple Diagram to estimate the dimension or rainwater tank required in the designed house in this study. From this graph, the difference in height between the average water demand and the cumulative rainfall line is 25395 litres, which is then used as the volume of rainwater harvesting needed.

$\mathrm{V}_{\mathrm{r}}=25395$ liters $=25.39 \mathrm{~m}^{3}$

Assume Height $=1.5 \mathrm{~m}$

Maximal Width (at available space on the ground) $=5 \mathrm{~m}$ Maximal Length (at available space on the ground) $=10$ m 
Width $=$ Length $=\mathrm{Y}$

$25.39 \mathrm{~m}^{3}=\mathrm{Y} \times \mathrm{Y} \times 1.5 \mathrm{~m}$

$\mathrm{Y}^{2}=25.39 / 1.5=16.9$

$\mathrm{Y}=4.11=4.2 \mathrm{~m}$ (it is still on the available space on the ground)

$\mathrm{V}=4.2 \times 4.2 \times 1.5=26.46 \mathrm{~m}^{3}$ so it is save for rainwater harvesting. Therefore, the size of water harvesting is $1.5 \mathrm{~m}$ height, $4.2 \mathrm{~m}$ width, and $4.2 \mathrm{~m}$ in length. Rainwater harvesting also has a large effect on the reduced amount of runoff water. This is because the rainwater that can inundate the surface of the ground can be collected and reused. This is certainly useful to reduce flood risk in the area.

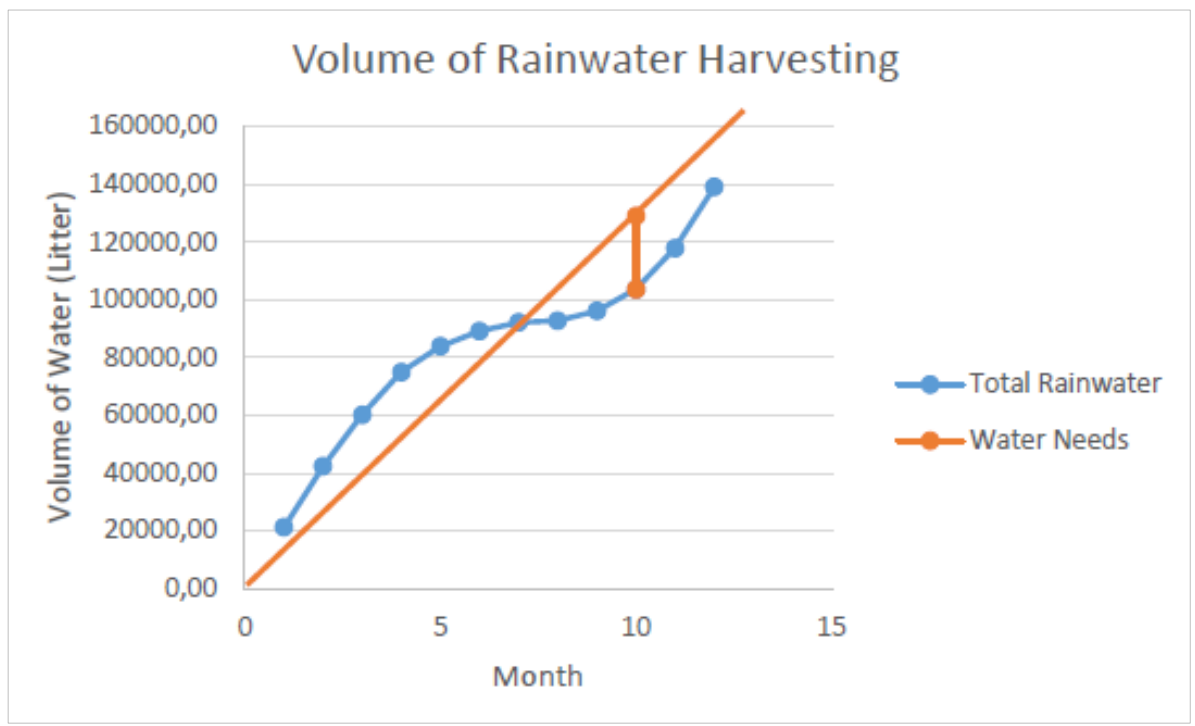

Figure 4. The Ripple Diagram to Estimate the Tank Dimension

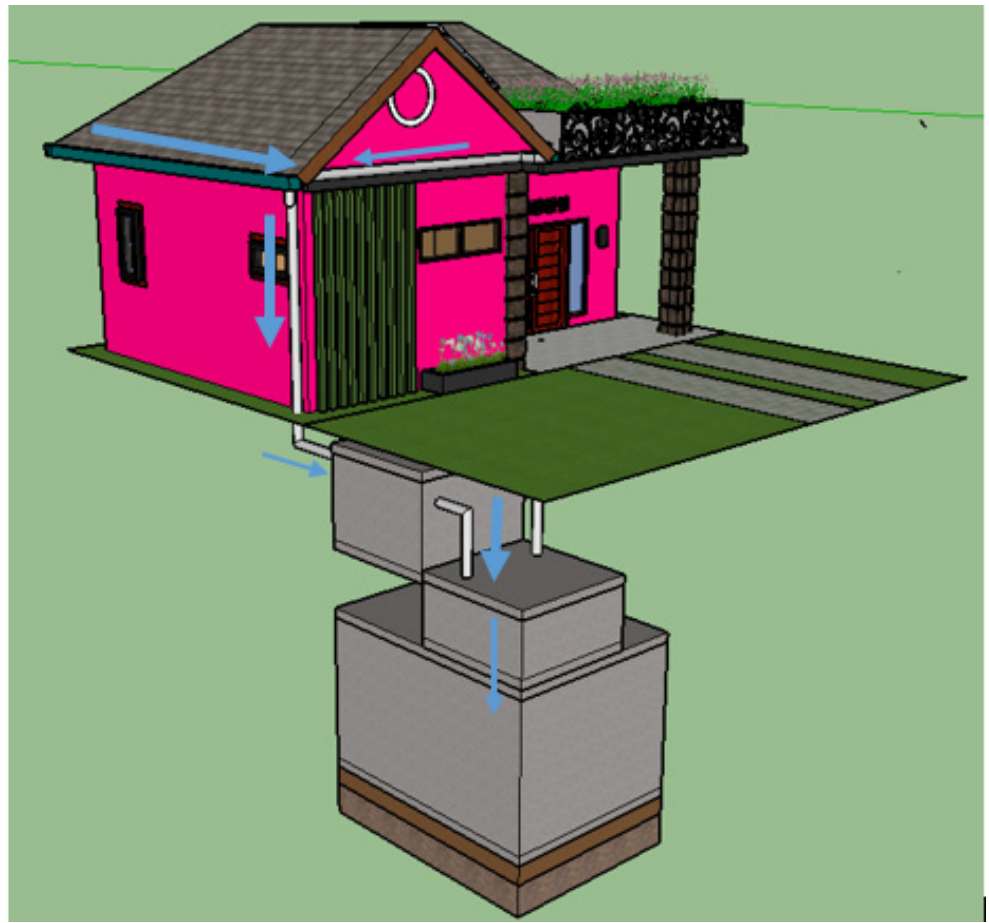

Figure 5. Rainwater Harvesting System 


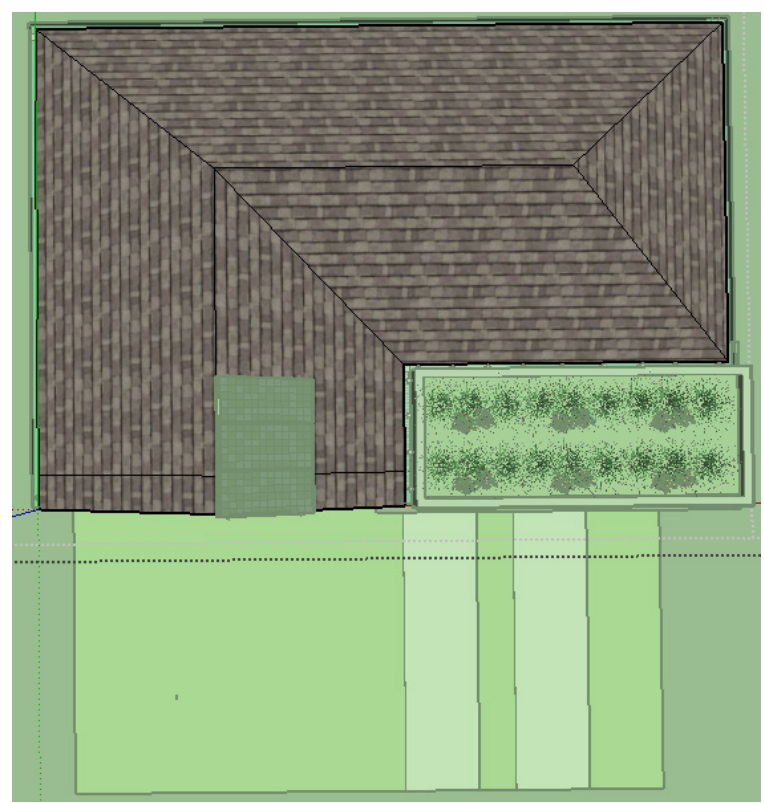

Figure 6. The Area of the Roof

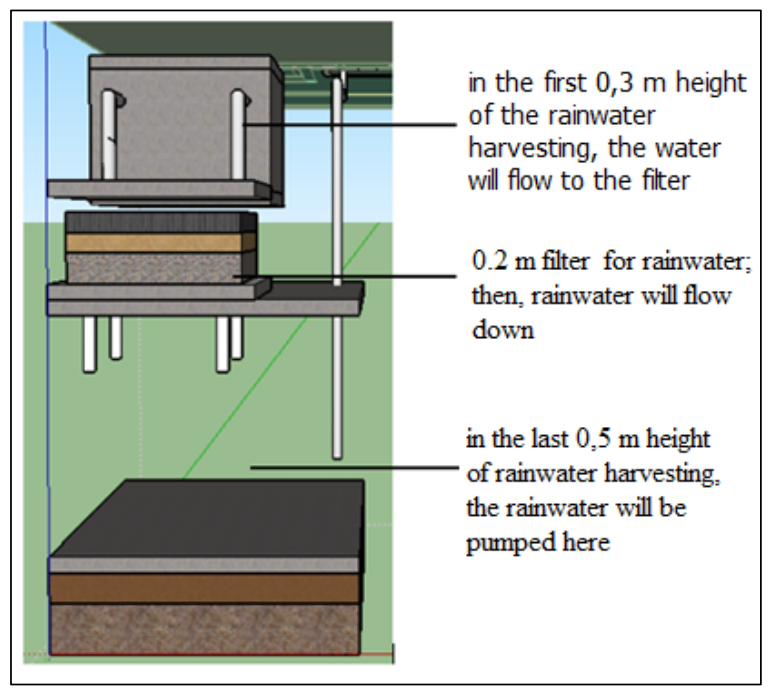

Figure 7. The Detail of the Rainwater Harvesting

\section{The Energy Required}

Water that has been filtered and stored in rainwater harvesting will again be reused for household needs, such as washing, bathing, and cooking. Of course, energy is needed so that water can rise from the shelter into the house. In the Indonesia market, examples of the pump sold in the market are Pump Type PL138 Bit which is automatic and Shimizu type PL138 bit 125 Watt for shallow wells. The Pump Type PL138 Bit uses an iron tube (without rubber/balloon). The Shimizu type PL138 bit 125 Watt is a cheap pump with good performance, and the brand is very well known in Indonesia. In addition, the Shimizu PL 138-bit pump is suitable for use in conventional homes. According to specifications available for the product, the value of the pump's criteria capacity is in the range of 28 litres per 10 minutes with electricity consumption of 125 watts per hour. So, to produce 480 litres of water per day, the pump takes as long as (480 litres / 28 litres) * 10 minutes $=171.43$ minutes.

The electrical power required to operate the pump for 171.43 minutes is:

$$
\begin{aligned}
& =125 \text { Watt } x(171.43 \text { minutes / 60) } \\
& =125 \text { Watt } x 2.86 \text { hours } \\
& =357.145 \text { Watt (per day) }
\end{aligned}
$$

\section{The Solar Cell Needed}

Solar Panel 100 WP Shinyoku Polycrystalline is the best efficiency Solar Cell Module, using solar cells with SiN layers that provide rural and urban electricity needs solutions for electricity saving solutions and other applications such as Solar Home System, Solar PJU, Solar Water Pump, Solar Power CCTV or Centralized Photo Voltaic System. But in this study, solar panels will only be used to meet the electricity needs of water pumps. Solar panel 100 WP means that the solar cell has 100-watt peaks (during the maximum hot sun). For one day with 4 hours of solar irradiance, so the solar cell will produce $100 \times 4=400$ Watt-hour/day, which is the maximum capacity for one-day usage. The pump in this study requires the power of 357.145 Watts, so only one unit of Polycrystalline is required. As for the supporting equipment such as batteries, converters, and inverters, for the first time purchase will be sold by the seller together in one package with the solar panel itself. Therefore the number and capacity of each item adjust to the needs of the solar panel used.

\section{Conclusions}

- The type of roof is 70 / 120 with four people inside, and the area of the roof is $76.61 \mathrm{~m}^{2}$ and the water needed for one day is 480 litres

- The type of green roof chosen is extensive by choosing the type of plant, namely sedum grass. The dimension of the concrete slab is $2.3 \mathrm{~m} \times 5.1 \mathrm{~m}$, with $0.8 \mathrm{~m}$ height of the soil layer with sedum.

- $\quad$ The selected rainwater harvesting capacity is 25,395 litres with the size is $4.10 \mathrm{~m}$ long, $4.10 \mathrm{~m}$ wide and 1.5 $\mathrm{m}$ high.

- The green roof and rainwater harvesting can reduce the amount of runoff water because the rainwater absorbed by plants and reused for household needs.

- $\quad$ The pump using one unit shallow well Shimizu PL 138 BIT and the energy needed for the pump per day is 357.145 watt/day. The selected solar panel is one unit Solar Panel 100 WP Shinyoku Polycrystalline. Solar panel $100 \mathrm{WP}$ means that the solar cell has 100-watt peaks (during the maximum hot sun). For one day with 4 hours solar irradiance, the solar cell 
will produce $100 \times 4=400$ Watt hour/day, which is the maximum capacity for one-day usage.

\section{Suggestions}

This paper is a result of a preliminary study, and to improve the result of further study, it is suggested that a small scale physical model of the green roof should be constructed to simulate the amount of rainwater which can be held/absorbed by the green roof. Therefore the reduced runoff can be estimated.

\section{Acknowledgements}

The authors would like to thank Universitas Muhammadiyah Surakarta, Indonesia, for giving support and funding; hence the paper can be produced. The authors also would like to thank and appreciate the reviewers for valuable corrections and suggestions to make this paper better than the first submitted one.

\section{REFERENCES}

[1] Ahmed. R.M, "An Evaluation of Green Roofing in
Building", Eastern Meditteranian University: International Journal of Scientific and Research Publications. 2016.

[2] Harto, S., “Analisis Hidrologi”. Jakarta: Gramedia Pustaka Utama, 1993.

[3] Jayasooriya, V.M, et al., "Optimal Sizing of Green Infrastructure Treatment Trains for Stormwater Management", Water Resour Manage (2016) 30:5407-5420, doi: 10.1007/s11269-016-1497-1, 2016

[4] Jothiprakash, V and Sathe, M.V, "Evaluation of Rainwater Harvesting Methods and Structures Using Analytical Hierarchy Process for a Large Scale Industrial Area", $J$. Water Resource and Protection, doi:10.4236/jwarp.2009.16 052 (http://www.scirp.org/journal/jwarp), 2009.

[5] Pudyastuti, P.S, and Saputra, M.M, "The Effect of Green Rooftop to Reduce Runoff (A Case Study at Selected Buildings in Surakarta City)", The $12^{\text {th }}$ SEATUC Symposium, Gadjah Mada University, 2018.

[6] SNI 03-7065-2005, "Tata Cara Perencanaan Sistem Plumbing”, Bandung: BSN (Badan Standarisasi Nasional), 2005.

[7] Sri Maharjono, Siti Qomariyah, Koosdaryani, “Analisis Dimensi Tangki PAH Guna Pemanfaatan Air Hujan Sebagai Sumber Air Cadangan Untuk Bangunan Rusunawa (Studi Kasus Rusunawa Semanggi, Surakarta)", e-Jurnal MATRIKS TEKNIK SIPIL/Maret 2017/258, 2017.

[8] Wilkinson, S. "Retrofitting Housing with Lightweight Greenroof Technology in Sydney, Australia, Rio de Jeneiro, and Brazil" University of Technology: MDPI Journal, 2015. 